\title{
Effect of Mowing Height on Dominance of Annual Poaceae Plants
}

\author{
Hidehiro Inagaki ${ }^{*}$, Chieko Saiki ${ }^{2}$, Minoru Ichihara², Kazuo Matsuno², \\ Yuuki Tanno', Masayuki Yamashita', Hitoshi Sawada' \\ 1 Shizuoka University, 836, Ohya, Suruga-ku, Shizuoka 422-8017, Japan \\ 2 Shizuoka Prefectural Research Institute of Agriculture and Forestry, 638-1, Tomigaoka, Iwata 438-0803, Japan \\ * Corresponding author's e-mail: hidehiro1_inagaki@pref.shizuoka.lg.jp
}

\begin{abstract}
Mowing weeds in rice paddy field ridges is essential for weed management. However, excessive mowing causes the dominance of the Poaceae weeds, which are host plants for rice stink bugs. In this study, the authors hypothesized that high mowing is more effective than low mowing in decreasing the dominance of Poaceae weeds. The dominance of the Poaceae weeds between high mowing (cut at a height of 5-10 cm) and low mowing (cut at ground level) was compared across 5 sites. As a result, the cover-abundance ratings of the Poaceae weeds were lower in the high mowing plots than that in the low mowing plots in all sites. In addition, the biodiversity index was higher in the high mowing plots than in the low mowing plots in each site. It was concluded that the increased mowing height effectively decreased the dominance of Poaceae weeds and this can be used as a strategy for controlling rice stink bugs.
\end{abstract}

Keywords: rice stink bugs, mowing height, poaceae weeds, biodiversity index, dominance

\section{INTRODUCTION}

In Japan, the damage of rice ears caused by rice stink bugs has become a serious problem for rice cultivation (Kuwazawa and Nakamura, 2006; Higuchi, 2010). The rice stink bugs, which include Cletus punctiger, Eysarcoris aeneus, Leptocorisa chinensis, Nezara viridula, are important economic pests in Japan [Fukui et al., 2006; Kiritani 2007]. In recent years, the damage caused by mirid species (Stenotus rubrovittatus and Trigonotylus caelestialium) has been increasing [Hayashi, 1997]. These rice stink bugs suck the ears of the Poaceae plants. They establish and reproduce in the ridges between rice paddy fields before invading the rice plants in paddies after the sprouting season [Teramoto, 2003; Kuwazawa and Nakamura, 2006; Yuasa, 2006]. As a result, Kuwazawa and Nakamura [2006] highlight the importance of weed control in ridges as well as inside the rice paddies. Herbicide treatment on ridges has been shown to be effective in controlling rice stink bugs because it kills the host plants, the Poaceae weeds [Niiyama and
Itoyama, 2006; Ueno, 2004; Takida, 2007]. Since the weeds growing in ridges reduce the water runoff and erosion damage, it is not desirable to kill all the weeds [Kusanagi et al., 1994]. Therefore, farmers have mainly used mowing as a weed control strategy in ridges. Previous studies indicate that frequent mowing prevents the heading of the Poaceae weeds, thereby reducing the infestation by rice stink bugs [Fujimaki et al., 1980; Hoshino et al., 1991; Ishikawa et al., 1995; Yamashiro et al., 1996; Teramoto, 2003; Kuwazawa and Nakamura, 2006]. However, it is difficult to prevent the heading of Poaceae weeds only by mowing. If mowing is not scheduled at an appropriate time or interval, the heading of Poaceae weeds will not be suppressed and the incidence of the rice stink bugs in the ridge will increase [Teramoto, 2003].

It is well-known that the diversity of flora in ridges is affected by the method of mowing [Otsuka et al., 2006; Yamaguchi et al., 1998]. As such, the authors hypothesized that changing the mowing height could suppress the overgrowth of the Poaceae weeds. Generally, the Poaceae plants have a tolerance towards the mowing pressure, 
because their growing point is positioned extremely low [Ito, 1993]. Furthermore, it has been reported that frequent mowing reduces the biodiversity of flora due to the dominance of a limited number of species that are adapted to frequent defoliation, such as lawn grass [Baba et al., 2003]. Therefore, increasing the mowing pressure could increase the risk of dominance of the Poaceae weeds and the incidence of rice stink bugs. In contrast, the reduced mowing pressure could enhance the survival rate of other plants and consequently, suppress the dominance of the Poaceae weeds. Increasing the mowing height and reducing the frequency of mowing are the two methods that can be used to reduce the mowing pressure. However, reducing the frequency of mowing has the risk of failing to suppress the growth of weeds. In addition, it is difficult to promote reduction in the frequency of mowing as a universal technology because of the contradictory effects of this strategy at different sites.

In this study, the authors focused on investigating the effect of increasing the mowing height on the dominance of the Poaceae weeds, which are host plants of rice stink bugs.

\section{STUDY SITE AND METHODS}

This study was conducted on 5 ridges (AC) of paddy fields located at different sites in
Table 1. Mowing time in experiment site

\begin{tabular}{|c|c|l|}
\hline \multicolumn{2}{|c|}{ Site } & \multicolumn{2}{|c|}{ Mowing time } \\
\hline A & Umeyama & Mid. of May Ear. of July Ear. of Aug. \\
\hline B & Kasahara & Mid. of July \\
\hline C & Mitsukawa & Mid. of July \\
\hline
\end{tabular}

the city of Fukuroi, Shizuoka Prefecture, Japan in 2009 (Table 1). Each ridge had three $5 \mathrm{~m}$ long test plots to which 2 mowing height treatments (high and low mowing) were randomly allocated. The high mowing plots were cut at a height of 5-10 cm while the low mowing plots were cut at the ground level and used as control. All the mowing work was done using brushcutter machines according to farmers' practices. The study was performed from May to August 2009, and the timing of mowing was according to the usual work schedule at each site (Table 1). On August 14, 2009, the authors measured the maximum plant height and Braun-Blanquet cover classes [BraunBlanquet, 1964] of all plant species occurring in $50 \times 100 \mathrm{~cm}$ quadrats (replicated 5 times in each plot). The height of the plant community was calculated from the weighted average degree of cover and the height of each plant species. In addition, the authors calculated the Shannon-Weaver diversity index [Shannon and Weaver, 1949] of each plant.

Table 2. Cover of principle plant species at each plot

\begin{tabular}{|c|c|c|c|c|c|c|}
\hline \multicolumn{2}{|c|}{ Site } & \multirow{2}{*}{\begin{tabular}{|r|} 
High mowing \\
Eragrostis ferruginea
\end{tabular}} & \multicolumn{2}{|l|}{ Cover(\%) } & \multirow{2}{*}{$\begin{array}{l}\text { Low mowing } \\
\text { Digitaria ciliaris }\end{array}$} & \multirow{2}{*}{$\begin{array}{c}\text { Cover }(\%) \\
\mathbf{8 7 . 5}\end{array}$} \\
\hline \multirow{5}{*}{$A$} & 1 & & 79.2 & 1 & & \\
\hline & 2 & Digitaria ciliaris & 8.3 & 2 & Eleusine indica & 4.2 \\
\hline & 3 & Aeschynomene indica & 4.2 & 3 & Cyperus microiria & 0.0 \\
\hline & 3 & Ipomoea hederacea & 4.2 & 3 & Ipomoea hederacea & 0.0 \\
\hline & 5 & Bidens frondosa & 0.0 & 3 & Eragrostis ferruginea & 0.0 \\
\hline \multirow{6}{*}{$\mathrm{B}$} & 1 & Bidens frondosa & 41.7 & 1 & Digitaria ciliaris & 45.8 \\
\hline & 2 & Digitaria ciliaris & 14.2 & 2 & Paspalum urvillei & 20.8 \\
\hline & 3 & Paspalum urvillei & 12.5 & 3 & Commelina communis & 8.3 \\
\hline & 4 & Commelina communis & 10.0 & 4 & Equisetum arvense & 1.7 \\
\hline & 5 & Aeschynomene indica & 1.7 & 5 & Aeschynomene indica & 0.0 \\
\hline & 5 & Solanum nigrum & 1.7 & & & \\
\hline \multirow{5}{*}{ C } & 1 & Commelina communis & 37.5 & 1 & Digitaria ciliaris & 70.8 \\
\hline & 2 & Conyza bonariensis & 21.9 & 2 & Oxalis corniculata & 8.3 \\
\hline & 3 & Oxalis corniculata & 6.9 & 3 & Alternanthera nodiflora & 4.2 \\
\hline & 4 & Solanum nigrum & 4.4 & 3 & Eclipta prostrata & 4.2 \\
\hline & 4 & Echinochloa crus-galli & 4.4 & 5 & Echinochloa crus-galli & 1.7 \\
\hline
\end{tabular}

Note: Shading is an annual Poaceae species which is host plant species of rice bug. 


\section{RESULTS}

Four annual Poaceae weeds - crab-grass (Digitaria ciliaris), foxtail (Setaria viridis), barnyard grass (Echinochloa crus-galli), and vaseygrass (Paspalum urvillei) - were recorded (Table 2). The cover degree of annual Poaceae weeds in the high mowing plots were lower than in the low mowing plots across all sites tested (Figure 1). There was little effect of high mowing on the cover degree of vaseygrass, which is perennial naturalized Poaceae weeds, in plot B. There is no difference of cover degree of all plants between the high mowing plots and the low mowing plots.

There was no consistent relationship between the mowing height and height of plant community across the 3 sites (Figure 2). In site A, the height of plant communities in the high mowing plots was higher than that in the low mowing plots. In sites B and $\mathrm{C}$, the height of plant communities did not differ between high mowing and low mowing plots.

The number of plant species in the high mowing plots was greater than that in the low mowing plots, even though this difference was statistically insignificant for all plots except $\mathrm{C}$ (Figure 3 ). The biodiversity index in the high mowing plots was also higher than that in the low mowing plots (Figure 4).

\section{DISCUSSION}

The mowing height is known to affect the composition and growth of plants and it is one of the simplest ways to alter the defoliation pressure. The effects of high mowing position has been studied in many situations such as apple orchard weed management [Toyoshima and Takanashi,

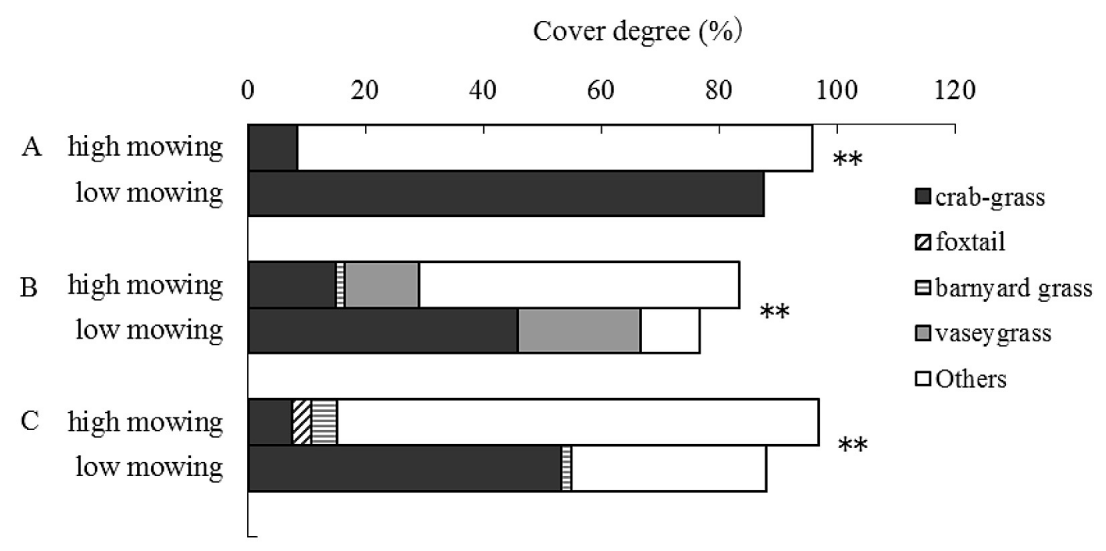

Figure 1. Cover-abundance ratings (\%) of annual Poaceae weeds in high mowing plots and low mowing plots ** indicates a significant difference $(\mathrm{p}<0.01, \mathrm{t}$-test $)$ in the cover degree of annual

Poaceae weeds between the high mowing and low mowing plots.

Height of plant community (cm)

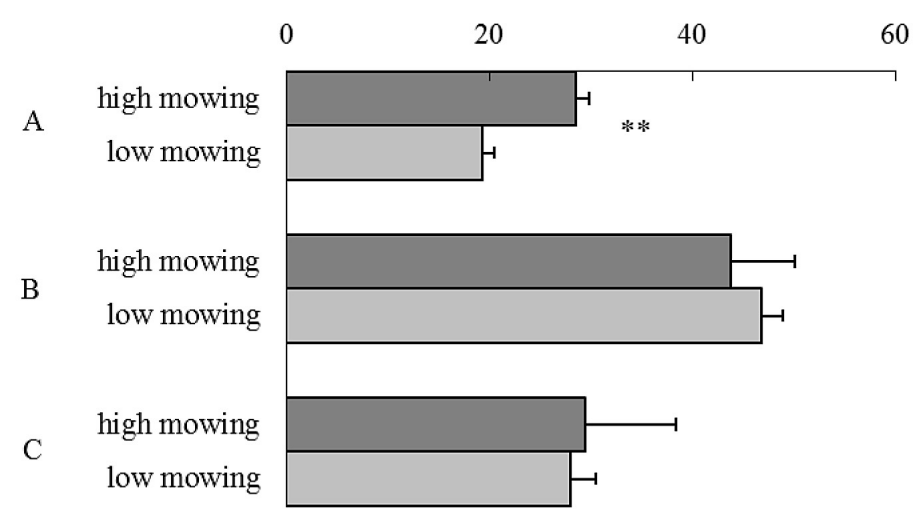

Figure 2. Effect of mowing height on plant community height

Bars represent standard deviation of 5 replicates.

** indicates a significant difference $(\mathrm{p}<0.01, \mathrm{t}$-test) between the high mowing and low mowing plots. 


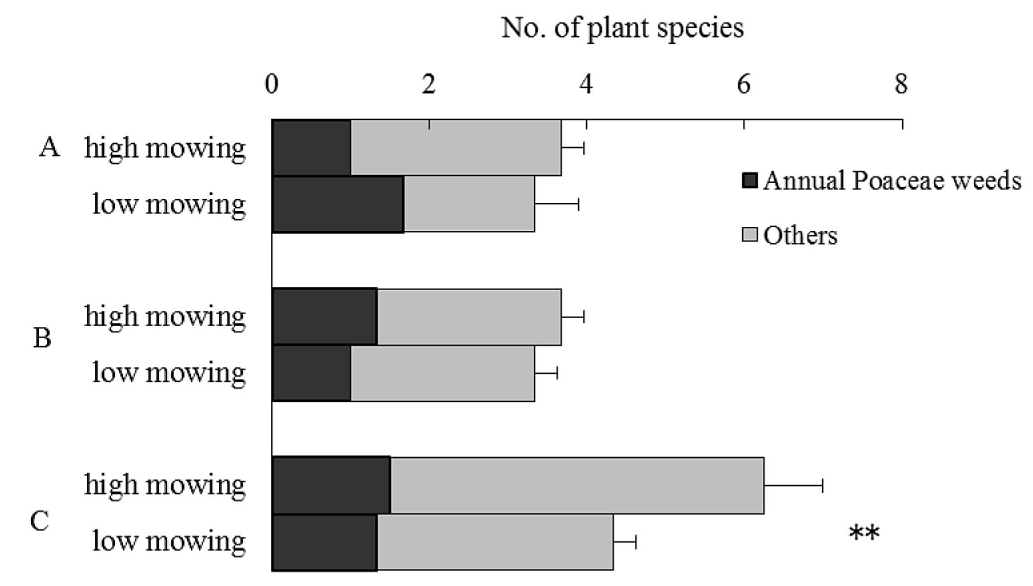

Figure 3. The number of plant species in high mowing and low mowing plots

Bars represent standard deviation of 5 replicates.

** indicates a significant difference $(\mathrm{p}<0.01, \mathrm{t}$-test) between the high mowing and low mowing plots.

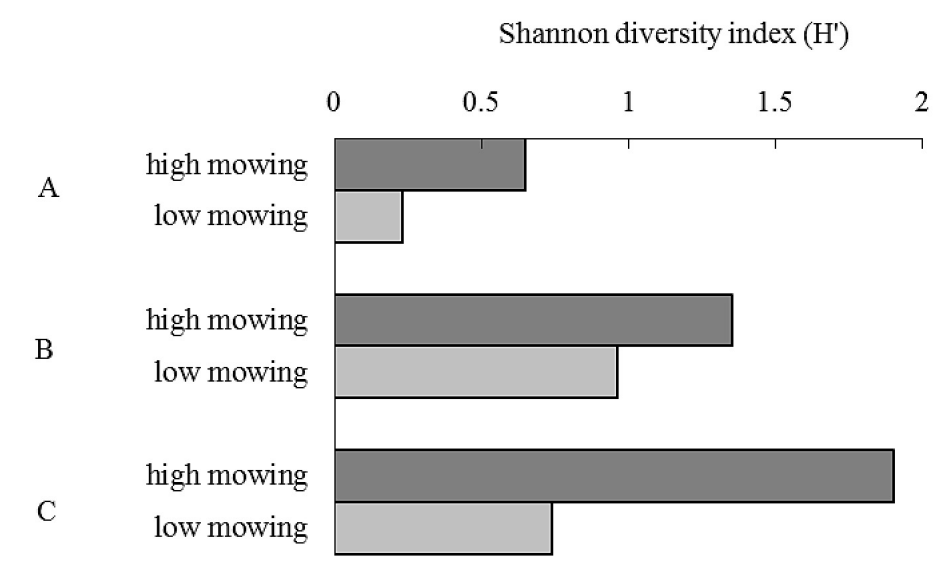

Figure 4. Shannon biodiversity index of plant species in high mowing and low mowing plots

2007], weed control in grasslands [Dernoeden et al., 1992], weed control in lawns [Davis, 1958; Hoyle, 2009], growth of lawn [Fagerness and Yelverton, 2001], and management of roadside vegetation [Zartman, 2011]. The present study proposes mowing at a high position for the control of the Poaceae plants as host plants of rice stink bugs. The results of this study revealed that mowing at high position prevents the dominance of annual Poaceae weeds. High mowing reduced the cover-abundance ratings of annual Poaceae weeds in all plots regardless of mowing time, which differed for each site. This suggests that high mowing is an effective method for the reduction of the rice stink bug incidence in rice paddy fields. However, it is important to note that the degree of the Poaceae weeds suppression differed significantly across sites. Further investigation is required in order to clarify the reason of this variation. The largest effect of high mowing was observed in site A where mowing was performed thrice during the experimental period. In sites B and $\mathrm{C}$, which were mowed only once during the same period, the effect was not as pronounced as in site A. The results seem to suggest that high mowing could be more effective if the mowing frequency is increased. However, it is necessary to consider the site differences, especially in relation to the type of native vegetation.

Yuasa [2006] proposed two strategies to control the weeds in ridges and hence, suppress the rice stink bugs infestation. The first strategy involves mowing frequently in order to prevent the heading of the Poaceae weeds. The second strategy prescribes suspending mowing after the heading of the Poaceae weeds in order to prevent the escape of rice stink bugs from the ridge into rice paddies. However, preventing the heading of the Poaceae weeds through the first strategy is difficult because they head over a long period of time. In addition, suspending mowing after heading does not fundamentally resolve the 
increase of rice stink bugs. In contrast, mowing at a high position, as proposed in this study, could be an effective method for a biological weed control. Further investigations are required to determine the optimum mowing height and to build the guidelines for identifying other plant species that are similarly affected by mowing at a high position.

Recently, an increase in the number of abandoned paddy fields has become a serious problem in Japan [Kusanagi, et al..1994; Ministry of Agriculture, Forestry and Fisheries, 2009]. Mowing has been used in the management of some of the abandoned paddy fields [Kusanagi et al., 1994], possibly resulting in an increase in the Poaceae weeds and consequently the rice stink bug infestations [Ito, 2004]. Mowing at a high position could be effective, not only for the management of weeds in ridges but also in the abandoned paddy fields.

However, mowing at a high position works by increasing the dominance of broad-leaved weeds rather than through a direct suppression of the Poaceae weeds. This is supported by the observation that in plot $\mathrm{B}$, the dominance of broadleaved weeds such as Bidens frondosa or Aeschynomene indica was increased by high mowing. This suggests that it is important to ensure that there are no harmful broad-leaved weeds in the original vegetation before using the high mowing strategy. The effectiveness of mowing at a high position would be low in the ridges with the Poaceae weeds only. This is because the high mowing method works by increasing the dominance of other plants that in turn suppresses the Poaceae weeds. Furthermore, it was suggested that there is a little effect of high mowing on the cover degree of vaseygrass, which is perennial naturalized Poaceae weeds. Therefore, the possible extensions and applications of this method to genetic weed management require further study.

Compared with low mowing, high mowing is unlikely to suppress the height of the weeds. The conducted study did not indicate consistent differences between high mowing and low mowing in terms of plant height. However, in site A, the plant height was $10 \mathrm{~cm}$ higher in the high mowing compared with the low mowing treatment. Therefore, the risk that weeds may grow more in response to mowing at a high position should be considered. Elucidation of the relationships between plant growth after mowing at a high position and the type of plant require further study.
The study also showed that the biodiversity index of plant species in high mowing is higher than that in low mowing in each site. Conserving plant biodiversity is important in rural areas [Takeuchi et al., 2001] and the ridges between paddy fields are important habitat areas for many plant species [Okubo et al., 2005; Otsuka et al., 2006; Yamaguchi et al., 1998]. The authors speculate that mowing at a high position could be an effective strategy to conserve the biodiversity of plants because it is a method that seems to suppress the Poaceae weeds, leaving the other plants to grow unhindered. Although a larger number of plant species was observed in high mowing compared with low mowing, the differences were statistically insignificant for all sites except for site C. It is possible that the number of plant species could be increased by repeated mowing at a high position over a longer period. A long-term study may be required to verify this effect since this study was carried out over a short period of time.

Although mowing weeds in ridges is essential for weed management, there is a risk that excessive mowing causes the dominance of the Poaceae weeds, resulting in the increase of rice stink bugs. As such, it was concluded that mowing at a high position is an effective method to reduce the dominance of the Poaceae weeds.

\section{REFERENCES}

1. Baba, T., Sonehara, N., Itoh, S., 2003. Vegetation change by grass cutting control on the paddy field embankment in Obasute area, Nagano Prefecture. J. Fac. Agric. Shinshu Univ. 39, 23-26. (In Japanese).

2. Braun-Blanquet, J., 1964. Pflanzensoziologie, Grundzage der vegetationskunde. Springer-Verlag, Berlin, Germany, pp. 865.

3. Davis, R.R. 1958. The effect of other species and mowing height on persistence of lawn grasses. Agron. J. 50:671-673.

4. Dernoeden, P.H., Carroll, M.J., Krouse, J.M. 1992. Weed management and tall fescue quality as influenced by mowing, nitrogen, and herbicides. Crop Sci. 33, 1055-1061.

5. Fagerness, M.J., Yelverton, F.H., 2001. Plant growth regulator and mowing height effects on seasonal root growth of penncross creeping bentgrass. Crop Sci. 41, 1901-1905.

6. Fujimaki, Y., Moriyama, S., Kojima, A., 1980. Reevaluation of a control method of speckled rice caused by bugs. Proc. Assoc. Plant Plot. Hokuriku 28, 51-53. (In Japanese). 
7. Fukui, T., Nishino, S., Matsumura, M., Doi, M., Hirooka, K., 2006. Occurrence of rice stinkbugs on centipede grass planted in rice field ridge. Bull Nara Agri. Exp. Sta 37, 25-30. (In Japanese).

8. Hayashi, H., 1997. Histrical changes and control of rice stink bug complex causing the pecky rice. Plant Prot. 51, 455-461. (In Japanese).

9. Higuchi, H., 2010. Ecology and management of rice bugs causing pecky rice. Jpn. J. Appl. Entomol. Zool. 54, 171-188. (In Japanese).

10. Hoshino, Y., Suzuki, R., Hasegawa, H., Honma, M., Maruyama, M., 1991. Chemical control of pecky rice with stink bugs by herbicides on levee and insecticides. Proc. Assoc. Plant Prot. Hokuriku 39, 63-65. (In Japanese).

11. Hoyle, J.A., 2009. Effect of mowing height in turfgrass systems on pest incidence. MSc Thesis, North Carolina State University, Raleigh, North Carolina.

12. Ishikawa, K., Tanaka, T., Komagata, K., Seki, M., 1995. Control of pecky rice by weed control of levee and insecticides. Proc. Asoc. Plant Plot Hokuriku 43, 13-16. (In Japanese).

13. Ito, K., 2004. A possible cause of recent outbreaks of rice-ear bugs-changes in the use of paddy field. Ann. Rept. Plant Prot. North Japan 55, 134-139. (In Japanese).

14. Ito, M., 1993. Weed science: Principles for weed control in Japan Yokendo Youkendo, Tokyo. (In Japanese).

15. Kiritani, K., 2007. The impact of global warming and land-use change on the pest status of rice and fruit bugs (Heteroptera) in Japan. Popul. Ecol. 48, 5-12.

16. Kusanagi, T., Konnai, M., Shibayama, H., eds 1994. Handbook of Weed Management Asakura Shoten, Tokyo. (In Japanese).

17. Kuwazawa, A., Nakamura, H., 2006. The relation between the abundance of stink bugs and the occurrence of spotted rice, and the impact of mowing in the ridge between rice fields on stink bugs. Bull. Shinshu Univ. 4, 57-63. (In Japanese).

18. Ministry of Agriculture, Forestry and Fisheries, 2009. Annual Report on Food, Agriculture and Rural Areas in Japan. http://www.maff.go.jp/e/annual report/2009/index.html Accessed August 23, 2012.

19. Niiyama, T., Itoyama, K., 2006. Control of rice leaf bug, Trigonotylus caelestialium (Heteroptera: Miridae) by application of herbicide to their source of imminigration. Ann. Rept. Plant Prot. North Japan 57, 129-133. (In Japanese).
20. Okubo, S., Kamiyama, A., Kitagawa, Y., Yamada, S., Palijon, A., Takeuchi, K., 2005. Management and micro-scale landform determine the ground flora of secondary woodlands and their verges in the Tama Hills of Tokyo, Japan. Biodivers. Conserv. $14,2137-2157$.

21. Otsuka, H., Nemoto, M Masuda, S., 2006. The floristic composition of paddy fields and their levees under different weed management techniques. J. Weed Sci. Tech. 51, 229-238. (In Japanese).

22. Shannon, C.E., Weaver, W., 1949. The mathematical theory of communication. The University of Illinois Press, Urbana, pp. 117.

23. Takeuchi, K., Wahitani, I., Tsunekawa, A., 2001. Satoyama: The Traditional Rural Landscape of Japan. University Tokyo Press, Tokyo, Japan.

24. Takida, M., 2007. Influence of weeding in the ridge on the premise that basic chemical control of Yamagata Prefecture and control effect of new systematic insecticide, for Trigonotylus caelestialium (Kirkaldy). Yamagata Pref. Agricultural Research 39, 55-67. (In Japanese).

25. Teramoto, N., 2003. Control of rice sting bug complex (hemiptera) in paddy fields by gramineous weed control on balks. Bull. Shiga Pref. Agri. Res. Center Agri. Exp. Sta 43, 47-70. (In Japanese).

26. Toyoshima, S., Takanashi, M., 2007. The effect of mowing at different heights on species composition of weeds in two apple orchards. Bull. Natl. Inst. Fruit Tree Sci. 6, 31-37. (In Japanese).

27. Ueno, K., 2004. Studies on control of pecky rice bugs in Yamagata Prefecture. Yamagata Pref. Agricultural Research 37, 53-78. (In Japanese).

28. Yamaguchi, H., Umemoto, S., Maenaka, H., 1998. Floral composition of the vegetation on levees of traditional and reconstructed paddies in Sakai city, Japan. J. Weed Sci. Tech. 43, 249-257. (In Japanese).

29. Yamashiro, C., Kojima, A., Fujimaki, Y., 1996. Control of speckled rice caused by bugs by weed control on levees of paddy field. Proc. Asoc. Plant Plot Hokuriku 44, 47-50. (In Japanese).

30. Yuasa, K., 2006. Relationships between weeds on levee of paddy fields and incidence of the rice sting bugs and pecky rice. Plant Protection 60, 211-214. (In Japanese),

31. Zartman, R.E., McKenney, C.B., Wester, D.B., Sosebee, R.E., Borrelli, J.B., 2011. Precipitation and mowing effects on highway rights-of-way vegetation height and safety. Landsc. Ecol. Eng. 18, 1-9. 